\begin{tabular}{l}
\hline OPEN OA ACCESS Freely available online \\
http://www.banglajol.info/index.php/BJID/index \\
Review Article \\
Bangladesh Journal of Infectious Diseases \\
April 2020, Volume 7, Number Suppl_1, Page S41-S44 \\
ISSN (Online) 2411-670X \\
ISSN (Print) 2411-4820 \\
DOI: https://doi.org/10.3329/bjid.v7i0.46800
\end{tabular}

\title{
Preventive and Control Measures of COVID-19 Patients: A Review
}

\author{
Tarek Mahbub Khan \\ Assistant Professor, Department of Virology, Sir Salimullah Medical College \& Mitford Hospital, Dhaka, Bangladesh
}

[Received: 31 March 2020; Accepted: 2 April 2020; Published: 25 April 2020]

\begin{abstract}
Covid19 is an acute respiratory disease which is caused by a novel coronavirus. This virus has been found in January 7, 2020 from China. The virus was previously known as 2019-nCOV. This particular virus is high chance of spread. Preventive measures are very essential for the health care workers. Proper preventive measures can only be applied to stop the spread of this virus. [Bangladesh Journal of Infectious Diseases, April 2020;7(suppl_1):S41-S44]

Keywords: Prevention; control measures; COVID-19 patients

Correspondence: Dr. Tarek Mahbub Khan, Assistant Professor, Department of Virology, Sir Salimullah Medical College \& Mitford Hospital, Dhaka, Bangladesh ; Cell no.: +8801711730121; Email: tarekviro@yahoo.com

Conflict of interest: All authors have no competing interests.

Funding agency: Authors received no financial support for research or publication of this article yet.

Contribution to authors: Khan TM has searched the literature and prepared the manuscript.

How to cite this article: Khan TM. Preventive and Control Measures of COVID-19 Patients: A Review. Bangladesh J Infect Dis 2020;7(suppl_1):S41-S44

Copyright: (02020. Khan. Published by Bangladesh Journal of Infectious Diseases. This article is published under the Creative Commons CC BY-NC License (https://creativecommons.org/licenses/by-nc/4.0/). This license permits use, distribution and reproduction in any medium, provided the original work is properly cited, and is not used for commercial purposes.
\end{abstract}

\section{Introduction}

An acute respiratory illness caused by a novel coronavirus was first reported in China. The virus has been nomenclature as SAR-COV2 which was previously known as 2019-nCOV ${ }^{1}$. This particular virus belongs to $\beta$-coronaviridae, is one of the three human coronavirus that caused human catastrophe since 2002 after SARS-COV and MERS-COV ${ }^{1}$. The virus infects upper and lower respiratory tract and binds more strongly to ACE2 receptor than its homologous virus SARS-COV. The most important routes of transmission are therefore through respiratory droplets and close contact ${ }^{2}$. 


\section{Chances of Transmission}

Droplet infection results from transmission of a water particle (usually 5-10 $\mu \mathrm{m}$ in diameter) containing virus. Direct human to human transmission occurs through air droplets among persons who are in close contact within 1 meter. Moreover, droplet infection has also been documented indirectly through surfaces of fomites ${ }^{3}$. Air-borne transmission may occur in special situation where aerosol generating medical or surgical procedures are under taken. However, in a study in China among 75465 COVID-19 cases no direct airborne transmission was recorded ${ }^{4}$. Although SARS-COV2 infects upper or lower respiratory tract, viral shedding in the blood is common, hence transmission of SARS-COV2 through blood is also a theoretical possibility ${ }^{5}$. It is crucial to know the transmission dynamics of infection for future plan and preparedness against spread of the disease ${ }^{6}$. Therefore, the strategy should emphasize to prevent droplet infections among the contacts with COVID19 patient and airborne precaution should be taken in special situations like tracheostomy, bronchoscopy, endotracheal intubation, open suctioning, manual ventilation? ${ }^{7}$.

\section{Importance of Prevention and Control Strategy}

Integrated community measures against SARS-COV 2 are important to control the spread of infection and disease. Several countries have taken different public health measures to reduce or delay the community transmission of COVID-19. Since there is no vaccine and specific anti-viral drugs so far, public health measures is considered as an effective tools to mitigate the impact of the virus in the community. The strategy includes community involvement where individuals develop the potentiality to prevent themselves from COVID-19 contacts as well as involvement of community based approach where planners, employers and community organizers can take strategy to protect vulnerable groups and the community against COVID-19 infection. Interestingly when the Wuhan incident started was the time for Chinese Lunar Holiday. This particular time has a high travelling rate among the homebound Chinese citizens who eventually came in close contact that facilitated the spread of transmission. Hence China focused on the conventional technique of public health outbreak response like isolation, quarantine, social distancing and community containment ${ }^{8}$. While controlling an outbreak of COVID-19 which is caused by an enveloped virus and predominantly transmitted through respiratory route, public health measures are out most important which includes hand hygiene, respiratory etiquette, social distancing, environment cleaning and securing safe handling of food. Moreover, an infection prevention control measure is similarly important for health care providers ${ }^{9}$.

\section{Hand Hygiene}

Hand is an important vehicle to transfer SARSCOV2. Frequent touching of mouth, nose or eye could recklessly bring the virus in contact with the mucosal surfaces. Hence the most important measure to control the spread of COVID-19 infection is frequent hand wash with soap and water or with an alcohol based hand sanitizer. If hands are not visibly dirty they should preferably have washed with alcohol based sanitizer for 20 to 30 seconds $^{10}$. However, if hands are visibly dirty they must wash with soap and water for 40 to 60 seconds with an appropriate protocol $^{11}$. Hand wash can protect a person from contracting this highly infectious virus and subsequent spread to others.

Indirect modes of transmission of COVID-19 are though fomites. Surfaces may get contaminated with infected hands or spills from respiratory droplets. An appropriate disinfection technique with $1.0 \%$ hypochlorite solution or $70.0 \%$ alcohol can limit the spread of infection.

\section{Use of Mask}

Prohibition of generalized use of masks by WHO is often criticized by some researchers. However using a surgical mask for COVID-19 patients, their care giver and health care workers (HCW) is well excepted ${ }^{9}$. Using an N95 mask or respirators is only restricted to any procedures like bronchoscopy, tracheostomy, manual ventilation, collection of respiratory samples or during other aerosol generating procedures ${ }^{9}$.

\section{Hospital Environment}

In a health care set-up, infection prevention control measures should be strictly followed. In the hospital there should be a system of well-maintained triage which is a first point of contact of suspected patient where patients are separated according case definition. It is mandatory for all suspects in the triage to wear surgical mask. The attending physicians should have PPE with surgical mask, however in case of any aerosol generating procedure and during sample collection a complete PPE is mandatory to 
protect health care worker from SARS-COV2 infection.

\section{Droplet Precaution}

Droplet precaution refers to prevention of large droplet transmission of respiratory viruses. As airdroplet seldom crosses beyond 1 meter, performing any work on patient near within 1 meter, all health care workers must wear medical/ surgical mask along with face shield or goggles to protect eye from accidental spiting from patients ${ }^{12}$.

\section{Contact Precaution}

Contact precaution prevents direct or indirect transmission from contaminated surface, fomites or instruments. Personal protective equipment (PPE) includes masks, gloves, gown, and goggles are necessary to prevent infection to health care workers. Dedicated instruments (stethoscope, thermometer) should be used for each patient however in case of sharing each instruments must be disinfected with alcohol or hypochlorite solution. Health care worker must avoid touching their mouth, nose or eye, frequent hand wash and a proper training on donning and doffing of PPE is very important to prevent spread of infection among them ${ }^{12}$.

\section{Airborne Precaution}

For obtaining airborne precaution it is obligatory for the health care workers to use complete PPE with N95 respirators during performing procedure that generates aerosol. Preferably it should be done in a negative air pressure room and should contain single person per room ${ }^{12}$. Covid19 virus has thought to be transmitted by aerosol. However, this is a new virus. It is still under investigation.

\section{Institutional Safeguard}

Apart from this health care set-up, during a pandemic attack institutional safeguard against COVID-19 infection is also important. Workplace are kept safe by promoting and facilitating hand hygiene, keeping distance of at least 1 meter, keep work surface and frequently touch sites like door knobs, telephone or computer key pad disinfected, prohibiting gathering by encouraging video conference, assess the risk of business travel, securing an isolated room for persons who suddenly get sick during work and encourage employee to get self-quarantine when having mild symptoms of COVID-19.

\section{Standard Measures}

In such situation when COVID-19 becomes major threat to public health, the institutional gathering is discouraged. In relation to that schools must have plans to ensure frequent hand hygiene for the students, ease accessible and available hand sanitizer and soap, frequent monitoring of hand wash practice, cough etiquette and holding program to sensitize the students about waste disposal. Classes should be rescheduled to avoid interclass gathering, if unavoidable hold classes in open air and well ventilated space, avoid food sharing, ensure safe health of persons work in the school cafeteria, advice students and staffs to stay home in self quarantine if suffer from mild symptoms of COVID-19.

\section{Conclusion}

A strong public health infrastructure is mandatory which can think proactively for future preparedness, development and research against emerging and reemerging infectious diseases. Investment for capacity building is crucial for rapid response through regional and global scientific and political collaboration to fight against future pandemic like COVID-19 13 .

\section{References}

1. Guo YR, Cao QD, Hong ZS, Tan YY, Chen SD, Jin HJ, Tan KS, Wang DY, Yan Y. The origin, transmission and clinical therapies on coronavirus disease 2019 (COVID-19) outbreak - an update on the status. Mil Med Res. 2020; 7(1):11

2. Liu J, Liao X, Qian S et al. Community transmission of severe acute respiratory syndrome coronavirus 2, Shenzhen, China, 2020. Emerg Infect Dis 2020

3. Ong SW, Tan YK, Chia PY, Lee TH, Ng OT, Wong MS, et al. Air, surface environmental, and personal protective equipment contamination by severe acute respiratory syndrome coronavirus 2 (SARS-CoV-2) from a symptomatic patient. JAMA. 2020 Mar 4 [Epub ahead of print].

4. World Health Organization. Report of the WHO-China Joint Mission on Coronavirus Disease 2019 (COVID-19) 16-24 February 2020 [Internet]. Geneva: World Health Organization; 2020 Available from: https://www.who.int/docs/defaultsource/coronaviruse/who-china-joint-mission-on-covid-19-finalreport.pdf

5. Chang L, Yan Y, Wang L. Coronavirus Disease 2019: Coronaviruses and Blood Safety. Transfus Med Rev. 2020 Feb 21. pii: S0887-7963(20)30014-6

6. Riley S, Fraser C, Donnelly CA, et al. Transmission dynamics of the etiological agent of SARS in Hong Kong: impact of public health interventions. Science 2003;300:1961-66

7. WHO Infection Prevention and Control Guidance for COVID19 available at https://www.who.int/emergencies/diseases/novelcoronavirus-2019/technical-guidance/infection-prevention-andcontrol. 
8. Wilder-Smith A, Freedman DO. Isolation, quarantine, social distancing and community containment: pivotal role for old-style public health measures in the novel coronavirus (2019-nCoV) outbreak. Journal of Travel Medicine. 2020;1-4

9. Infection Prevention and Control during health care when novel coronavirus (Ncov) infection is suspected: interim guidance, World Health Organization, January 15, 2020.

10. Siddharta A, Pfaender S, Vielle NJ, Dijkman R, Friesland M, Becker B, et al. Virucidal activity of World Health Organizationrecommended formulations against enveloped viruses, including Zika, Ebola, and emerging coronaviruses. J Infect Dis. 2017;215(6):902-6
11. WHO guidelines on hand hygiene in health care settings. Geneva: World Health Organization; 2009 (https://apps.who.int/iris/bitstream/handle/10665/44 102/9789241597906_eng.pdf?sequence=1\&isAllow ed=y, accessed 3 March 2020).

12. Clinical Management of Severe Acute Respiratory Illness (SARI) when COVID-19 disease is suspected: interim guidance. World Health Organization, March 13, 2020.

13. $\mathrm{Wu} \mathrm{Z,} \mathrm{McGoogan} \mathrm{JM.} \mathrm{Characteristics} \mathrm{of} \mathrm{and} \mathrm{Important}$ Lessons from the Coronavirus Disease 2019 (COVID-19) Outbreak in China: Summary of a Report of 72314 Cases from the Chinese Center for Disease Control and Prevention. JAMA 2020;323(13):1239-1242 